\title{
Effects of Carissa opaca fruits extracts on oxidative pulmonary damages and fibrosis in rats
}

Sumaira Sahreen ${ }^{1,2^{*}}$, Muhammad Rashid Khan ${ }^{2}$ and Rahmat Ali Khan ${ }^{2,3^{*}}$

\begin{abstract}
Background: Carissa opaca is a Pakistani fruit, traditionally used in the treatment of various human ailments including asthma and pulmonary damage. The present study investigated the protective effects of Carissa opaca against $\mathrm{CCl}_{4}$-induced oxidative stress in rat lungs.

Methods: To assess the protective effects of Carissa opaca, 42 Sprague-Dawley male rats (170-180 g) were randomly divided into 7 groups. Group I was untreated and group II received olive oil intraperitoneally (i.p.) and dimethyl sulfoxide orally. Groups III, IV, V, VI and VII were administered $\mathrm{CCl}_{4}, 3 \mathrm{ml} / \mathrm{kg}$ bodyweight (30\% in olive oil i.p.). Group IV was administered $50 \mathrm{mg} / \mathrm{kg}$ bodyweight silymarin whereas groups V, VI and VII were treated with $200 \mathrm{mg} / \mathrm{kg}$ of various fractions of Carissa opaca after $48 \mathrm{~h}$ of $\mathrm{CCl}_{4}$ treatment for eight weeks. Antioxidant profiles in lungs were evaluated by estimating the activities of antioxidant enzymes: catalase, peroxidase, superoxide dismutase, glutathione-S-transferase, glutathione reductase, glutathione peroxidase, quinone reductase and reduced glutathione. $\mathrm{CCl}_{4}$-induced lipid peroxidation was determined by measuring the level of thiobarbituric acid reactive substances (TBARS) with conjugation of DNA damage and histopathology.

Results: Administration of $\mathrm{CCl}_{4}$ for 8 weeks significantly reduced $(p<0.05)$ the activities of antioxidant enzymes and GSH concentration while increasing TBARS content and DNA damage. Co-treatment of various fractions of Carissa opaca and silymarin restored the activities of antioxidant enzymes and glutathione content. Changes in TBARS concentration and DNA fragmentation was significantly decreased $(p<0.05)$ following Carissa opaca and silymarin treatment in lung.
\end{abstract}

Conclusions: Histopathological changes in rat lungs induced by $\mathrm{CCl}_{4}$ were significantly restored by co-treatment with Carissa opaca and silymarin.

Keyword: Carissa opaca, Lungs, CCl4, Antioxidant enzymes, TBARS, DNA

\section{Background}

Exposure to UV radiation, X-rays, environmental pollutants, toxic chemicals and excessive drug use causes the production of free radicals and reactive oxygen species that lead to oxidative damage in the kidney, liver and lungs [1]. The lung is the main organ of respiration and is exposed to higher oxygen stress compared with other tissues. Exogenous oxidants, cigarette smoke and asbestos fibers activate inflammatory cells to generate oxidative stress and lung fibrosis [1]. Several important reactive

\footnotetext{
* Correspondence: sumairasahreen@yahoo.com; rahmatgul_81@yahoo.com 'Botanical Sciences Division, Pakistan Museum of Natural History, Garden Avenue, Shakarparian, Islamabad, Pakistan

${ }^{2}$ Department of Biotechnology, University of Science and Technology, Bannu, KPK, Pakistan

Full list of author information is available at the end of the article
}

oxygen species (ROS) are generated endogenously in these circumstances [2], which include superoxide radicals, hydrogen peroxide $\left(\mathrm{H}_{2} \mathrm{O}_{2}\right)$, and hydroxyl radicals. The major enzymes/reaction pathways that are activated to generate ROS in human lungs include nicotinamide adenine dinucleotide phosphate oxidases, myeloperoxidase, eosinophil peroxidase, mitochondrial electron transport chain, and possibly xanthine oxidase [3]. A balance between intracellular and extracellular oxidants and antioxidants is a prerequisite for normal lung homeostasis. The lung has highly specialized and compartmentalized antioxidant defenses to protect against ROS and reactive nitrogen species. Induction of these antioxidant enzymes and related proteins after pulmonary insults may protect the lung and promote normal repair. Conversely, impaired

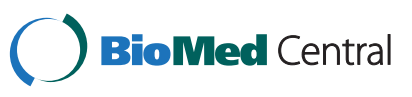


induction or inactivation/clearance of antioxidant enzymes may result in a sustained redox imbalance that may contribute to the progression of pulmonary fibrosis [4].

Plants are commonly used for the discovery of new therapeutic products. In recent years, there has been increasing interest in finding natural antioxidants from commonly available wild plants, fruits and vegetables [5] as well as their important role in detoxification of free radical-induced lung injuries and fibrosis in experimental animal models [6]. Carissa opaca (C. opaca) Stapf ex Hanes is a 2-3 meter tall evergreen shrub containing glabrous fruits widely found in Pakistan [7]. Traditionally this plant is used for the treatment of asthma [8], hepatitis [9], diarrhea [10] and renal dysfunction [11]. The present study examined the toxic effects of $\mathrm{CCl}_{4}$ and investigated the beneficial effects of plant extracts on tissues from various $\mathrm{CCl}_{4}$-induced lung damage experimental groups.

\section{Methods and Materials Plant collection}

C. opaca ripened fruits were collected in March-April 2011 from the Quaid-i-Azam University Islamabad, Pakistan. The plants were recognized by their local names and then validated by Dr. Mir Ajab Khan, Department of Plant Sciences, Quaid-i-Azam University, Islamabad. A voucher specimen with Accession No. 24561 (C. opaca) was deposited at the Herbarium of Pakistan Quaid-i-Azam University, Islamabad Pakistan.

\section{Extract preparation}

The collected fruits were cleaned to get rid of dust particles and then dried under shade for one to two weeks. Willy Mill of 60-mesh size was used to prepare powder of dried samples. $5 \mathrm{~kg}$ of powdered sample was extracted twice with $10 \mathrm{~L}$ of $95 \%$ methanol at $25^{\circ} \mathrm{C}$ for $48 \mathrm{~h}$. For filtration Whatman No. 1 filter paper was used and then filtrate was concentrated through rotary evaporator (Panchun Scientific Co., Kaohsiung, Taiwan) under reduced pressure at $40^{\circ} \mathrm{C}$. In order to resolve the compounds with escalating polarity, a part of the extract was suspended in distilled water and subjected to liquid-liquid partition by using solvents in a sequence of n-hexane and ethyl acetate. After fractioning, the solvent of respective fractions was also evaporated by rotary evaporator. Extract was dried and then stored at $4^{\circ} \mathrm{C}$ for further in vivo investigation.

\section{Experimental plan}

Six-week-old male Sprague Dawley rats weighing $180 \pm$ $10 \mathrm{~g}$ were provided with food and water ad libitum and kept at $20-22^{\circ} \mathrm{C}$ on a 12 -h light/dark cycle. All experimental procedures involving animals were conducted in accordance with the guidelines of National Institutes of Health (NIH guidelines). The study protocol were approved by Ethical committee of Quaid-i-Azam University
Islamabad. The rats were acclimatized to laboratory condition for 7 days before commencement of experiment. For chronic toxicity eight week experiment was designed. 42 male albino rats were randomly divided into seven groups (6 rats of each group). Administration of $\mathrm{CCl}_{4}(0.5 \mathrm{ml} / \mathrm{kg}$ b.w., $20 \% \mathrm{CCl}_{4} /$ olive oil) was intraperitoneally (i.p.) twice a week for eight weeks. At the same time, the rats were administered individually silymarin $(50 \mathrm{mg} / \mathrm{kg}$ b.w.) and extract (200 mg/kg b.w.) orally twice a week for eight weeks.

\section{Experimental protocol}

Following dosing plan was adapted for the study.

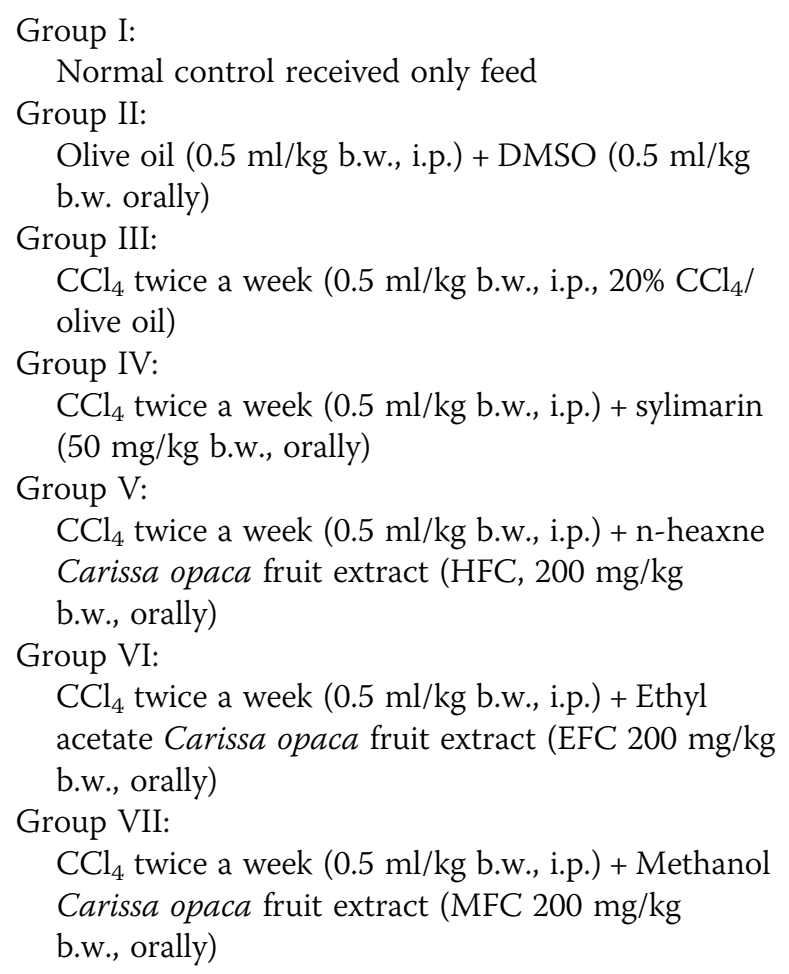

At the end of eight weeks, after $24 \mathrm{~h}$ of the last treatment, animals were given chloroform anesthesia and dissected from ventral side. All the animals were sacrificed; lungs were removed and washed in ice cold saline. Subsequently, half of the organs were treated with liquid nitrogen and stored at $-80^{\circ} \mathrm{C}$ for further enzymatic and DNA damage analysis while the other portion was processed for histology.

\section{Biochemical investigations}

In order to evaluate the pharmacological effects of different fractions of C. opaca against the toxicity induced with $\mathrm{CCl}_{4}$ in rats following assays had been carried out.

\section{Assessment of antioxidant enzymes}

$10 \%$ tissue homogenate was prepared in $100 \mathrm{mM} \mathrm{KH_{2 }} \mathrm{PO}_{4}$ buffer containing $1 \mathrm{mM}$ EDTA (pH 7.4) and centrifuged 
at $12,000 \times \mathrm{g}$ for $30 \mathrm{~min}$ at $4^{\circ} \mathrm{C}$. The supernatant was collected and used for the following parameters as described below.

\section{Catalase assay (CAT)}

CAT activities were determined by the method of Chance and Maehly [12] with some modifications. The reaction solution of CAT activities contained: $2.5 \mathrm{ml}$ of $50 \mathrm{mM}$ phosphate buffer ( $\mathrm{pH} 5.0$ ), $0.4 \mathrm{ml}$ of $5.9 \mathrm{mM} \mathrm{H}_{2} \mathrm{O}_{2}$ and $0.1 \mathrm{ml}$ enzyme extract. Changes in absorbance of the reaction solution at $240 \mathrm{~nm}$ were determined after one minute. One unit of CAT activity was defined as an absorbance change of 0.01 as units/min.

\section{Peroxidase assay (POD)}

Activities of POD were determined by the method of Chance and Maehly [12] with some modifications. The POD reaction solution contained: $2.5 \mathrm{ml}$ of $50 \mathrm{mM}$ phosphate buffer (pH 5.0), $0.1 \mathrm{ml}$ of $20 \mathrm{mM}$ guaiacol, $0.3 \mathrm{ml}$ of $40 \mathrm{mM} \mathrm{H}_{2} \mathrm{O}_{2}$ and $0.1 \mathrm{ml}$ enzyme extract. Changes in absorbance of the reaction solution at $470 \mathrm{~nm}$ were determined after one minute. One unit of POD activity was defined as an absorbance change of 0.01 units $/ \mathrm{min}$.

\section{Superoxide dismutase assay (SOD)}

SOD activity was estimated by the method of Kakkar et al. [13]. Reaction mixture of this method contained: $0.1 \mathrm{ml}$ of phenazine methosulphate $(186 \mu \mathrm{M}), 1.2 \mathrm{ml}$ of sodium pyrophosphate buffer (0.052 mM; pH 7.0), $0.3 \mathrm{ml}$ of supernatant after centrifugation $(1500 \times \mathrm{g}$ for $10 \mathrm{~min}$ followed by $10000 \times \mathrm{g}$ for $15 \mathrm{~min}$ ) of lung homogenate was added to the reaction mixture. Enzyme reaction was initiated by adding $0.2 \mathrm{ml}$ of $\mathrm{NADH}(780 \mu \mathrm{M})$ and stopped after $1 \mathrm{~min}$ by adding $1 \mathrm{ml}$ of glacial acetic acid. Amount of chromogen formed was measured by recording color intensity at $560 \mathrm{~nm}$. Results are expressed in units/mg protein.

\section{Glutathione-S-transferase assay (GST)}

Glutathione-S-transferase activity was assayed by the method of Habig et al. [14]. The reaction mixture consisted of $1.475 \mathrm{ml}$ phosphate buffer $(0.1 \mathrm{~mol}, \mathrm{pH} 6.5)$, $0.2 \mathrm{ml}$ reduced glutathione $(1 \mathrm{mM}), 0.025 \mathrm{ml}(\mathrm{CDNB})$ $(1 \mathrm{mM})$ and $0.3 \mathrm{ml}$ of homogenate in a total volume of $2.0 \mathrm{ml}$. The changes in the absorbance were recorded at $340 \mathrm{~nm}$ and enzymes activity was calculated as nM CDNB conjugate formed $/ \mathrm{min} / \mathrm{mg}$ protein using a molar extinction coefficient of $9.6 \times 10^{3} \mathrm{M}^{-1} \mathrm{~cm}^{-1}$.

\section{Glutathione reductase assay (GR)}

Glutathione reductase activity was determined by method of Carlberg and Mannervik [15]. The reaction mixture consisted of $1.65 \mathrm{ml}$ phosphate buffer: (0.1 mol; pH 7.6), $0.1 \mathrm{ml}$ EDTA $(0.5 \mathrm{mM}), 0.05 \mathrm{ml}$ oxidized glutathione $(1 \mathrm{mM})$, $0.1 \mathrm{ml} \mathrm{NADPH}(0.1 \mathrm{mmol})$ and $0.1 \mathrm{ml}$ of homogenate in a total volume of $2 \mathrm{ml}$. Enzyme activity was quantitated at $25^{\circ} \mathrm{C}$ by measuring disappearance of NADPH at $340 \mathrm{~nm}$ and was calculated as nM NADPH oxidized/ $\mathrm{min} / \mathrm{mg}$ protein using molar extinction coefficient of $6.22 \times 10^{3} \mathrm{M}^{-1} \mathrm{~cm}^{-1}$.

\section{Glutathione peroxidase assay (GPx)}

Glutathione peroxidase activity was assayed by the method of Mohandas et al. [16]. The reaction mixture consisted of $1.49 \mathrm{ml}$ phosphate buffer (0.1 M; pH 7.4), $0.1 \mathrm{ml}$ EDTA (1 mM), $0.1 \mathrm{ml}$ sodium azide $(1 \mathrm{mM}), 0.05 \mathrm{ml}$ glutathione reductase ( $1 \mathrm{IU} / \mathrm{ml}), 0.05 \mathrm{ml}$ GSH $(1 \mathrm{mM}), 0.1 \mathrm{ml} \mathrm{NADPH}$ (0.2 mM), $0.01 \mathrm{ml} \mathrm{H}_{2} \mathrm{O}_{2}(0.25 \mathrm{mM})$ and $0.1 \mathrm{ml}$ of homogenate in a total volume of $2 \mathrm{ml}$. The disappearance of $\mathrm{NADPH}$ at $340 \mathrm{~nm}$ was recorded at $25^{\circ} \mathrm{C}$. Enzyme activity was calculated as nM NADPH oxidized $/ \mathrm{min} / \mathrm{mg}$ protein using molar extinction coefficient of $6.22 \times 10^{3} \mathrm{M}^{-1} \mathrm{~cm}^{-1}$.

\section{Quinone reductase assay (QR)}

The activity of quinone reductase was determined by the method of Benson et al. [17]. The $3.0 \mathrm{ml}$ reaction mixture consisted of $2.13 \mathrm{ml}$ Tris- $\mathrm{HCl}$ buffer $(25 \mathrm{mM}$; $\mathrm{pH}$ 7.4), $0.7 \mathrm{ml} \mathrm{BSA}, 0.1 \mathrm{ml}$ FAD, $0.02 \mathrm{ml} \mathrm{NADPH}$ (0.1 $\mathrm{mM})$, and $0.1 \mathrm{ml}$ of homogenate. The reduction of dichlorophenolindophenol (DCPIP) was recorded at $600 \mathrm{~nm}$ and enzyme activity was calculated as $\mathrm{nM}$ of DCPIP reduced $/ \mathrm{min} / \mathrm{mg}$ protein using molar extinction coefficient of $2.1 \times 10^{4} \mathrm{M}^{-1} \mathrm{~cm}^{-1}$

\section{Reduced glutathione assay (GSH)}

Reduced glutathione was estimated by the method of Jollow et al. [18]. $1.0 \mathrm{ml}$ sample of homogenate was precipitated with $1.0 \mathrm{ml}$ of (4\%) sulfosalicylic acid. The samples were kept at $4^{\circ} \mathrm{C}$ for $1 \mathrm{~h}$ and then centrifuged at $1200 \times \mathrm{g}$ for $20 \mathrm{~min}$ at $4^{\circ} \mathrm{C}$. The total volume of $3.0 \mathrm{ml}$ assay mixture contained $0.1 \mathrm{ml}$ filtered aliquot, $2.7 \mathrm{ml}$ phosphate buffer (0.1 M; pH 7.4) and $0.2 \mathrm{ml} \mathrm{DTNB}$ (100 mM). The yellow color developed was read immediately at $412 \mathrm{~nm}$ on a SmartSpecTM plus Spectrophotometer. It was expressed as $\mu \mathrm{M} \mathrm{GSH} / \mathrm{g}$ tissue.

\section{Estimation of lipid peroxidation assay (TBARS/LPO)}

The assay for lipid peroxidation was carried out following the modified method of Iqbal et al. [19]. The reaction mixture in a total volume of $1.0 \mathrm{ml}$ contained $0.58 \mathrm{ml}$ phosphate buffer $(0.1 \mathrm{M}$; pH 7.4), $0.2 \mathrm{ml}$ homogenate sample, $0.2 \mathrm{ml}$ ascorbic acid $(100 \mathrm{mM})$, and $0.02 \mathrm{ml}$ ferric chloride $(100 \mathrm{mM})$. The reaction mixture was incubated at $37^{\circ} \mathrm{C}$ in a shaking water bath for $1 \mathrm{~h}$. The reaction was stopped by addition of $1.0 \mathrm{ml} \mathrm{10 \%} \mathrm{trichloroacetic} \mathrm{acid.}$ Following addition of $1.0 \mathrm{ml} 0.67 \%$ thiobarbituric acid, all the tubes were placed in boiling water bath for $20 \mathrm{~min}$ and then shifted to crushed ice-bath before centrifuging at $2500 \times \mathrm{g}$ for $10 \mathrm{~min}$. The amount of TBARS formed in 
each of the samples was assessed by measuring optical density of the supernatant at $535 \mathrm{~nm}$ using spectrophotometer against a reagent blank. The results were expressed as $\mathrm{nM}$ TBARS $/ \mathrm{min} / \mathrm{mg}$ tissue at $37^{\circ} \mathrm{C}$ using molar extinction coefficient of $1.56 \times 10^{5} \mathrm{M}^{-1} \mathrm{~cm}^{-1}$.

\section{Hydrogen peroxide assay $\left(\mathrm{H}_{2} \mathrm{O}_{2}\right)$}

Hydrogen peroxide $\left(\mathrm{H}_{2} \mathrm{O}_{2}\right)$ was assayed by $\mathrm{H}_{2} \mathrm{O}_{2}$-mediated horseradish peroxidase-dependent oxidation of phenol red by the method of Pick and Keisari [20]. $2.0 \mathrm{ml}$ of homogenate sample was suspended in $1.0 \mathrm{ml}$ of solution containing phenol red $(0.28 \mathrm{nM})$, horse radish peroxidase (8.5 units), dextrose $(5.5 \mathrm{nM})$ and phosphate buffer (0.05 M; pH 7.0) and were incubated at $37^{\circ} \mathrm{C}$ for $60 \mathrm{~min}$. The reaction was stopped by the addition of $0.01 \mathrm{ml}$ of $\mathrm{NaOH}(10 \mathrm{~N})$ and then centrifuged at $800 \times \mathrm{g}$ for $5 \mathrm{~min}$. The absorbance of the supernatant was recorded at $610 \mathrm{~nm}$ against a reagent blank. The quantity of $\mathrm{H}_{2} \mathrm{O}_{2}$ produced was expressed as $\mathrm{nM} \mathrm{H}_{2} \mathrm{O}_{2} / \mathrm{min} / \mathrm{mg}$ tissue based on the standard curve of $\mathrm{H}_{2} \mathrm{O}_{2}$ oxidized phenol red.

\section{Molecular studies}

DNA had been isolated and its fragmentation percent was quantified in molecular studies of in vivo toxicity.

\section{DNA fragmentation assay with diphenylamine reaction}

DNA fragmentation from tissue extract was determined using the procedure of Wu et al. [21]. $100 \mathrm{mg}$ tissue was homogenized in TTE solution. $0.1 \mathrm{ml}$ of homogenate was labeled B, centrifuged at $200 \times \mathrm{g}$ at $4^{\circ} \mathrm{C}$ for $10 \mathrm{~min}$, got supernatant labeled $\mathrm{S}$. $\mathrm{S}$ tubes were centrifuged at $20,000 \times \mathrm{g}$ for $10 \mathrm{~min}$ at $4^{\circ} \mathrm{C}$ to separate intact chromatin, was labeled T. $1.0 \mathrm{ml}$ of $25 \%$ TCA was added in all tubes $\mathrm{T}, \mathrm{B}, \mathrm{S}$ and incubated over night at $4^{\circ} \mathrm{C}$. After incubation precipitated DNA was recovered by pelleting for $10 \mathrm{~min}$ at $18,000 \times \mathrm{g}$ at $4^{\circ} \mathrm{C} .160 \mu \mathrm{l}$ of $5 \%$ TCA was added to each pellet and heated for $15 \mathrm{~min}$ at $90^{\circ} \mathrm{C}$ then $320 \mu \mathrm{l}$ of freshly prepared DPA solution was added, vortexed and incubated for $4 \mathrm{hr} 37^{\circ} \mathrm{C}$. Optical density was read at $600 \mathrm{~nm}$ with a spectrophotometer (Smart $\operatorname{spec}^{\mathrm{TM}}$ Plus, catalog \# 170-2525).

\section{DNA Isolations and ladder assay}

DNA was isolated by using the methods of $\mathrm{Wu}$ et al. [21]. $100 \mathrm{mg}$ of tissue in a petri dish was washed with DNA Buffer and homogenized in $1 \mathrm{ml}$ lysis buffer. $100 \mu \mathrm{l}$ of proteinase $\mathrm{K}(10 \mathrm{mg} / \mathrm{ml})$ and $240 \mu \mathrm{l} 10 \% \mathrm{SDS}$, shaked gently, and incubate overnight at $45^{\circ} \mathrm{C}$ in a water bath then $0.4 \mathrm{ml}$ of phenol, was added shaked for 5-10 min, and centrifuge at $3000 \mathrm{rpm}$ for $5 \mathrm{~min}$ at $10^{\circ} \mathrm{C}$. Supernatant was mixed with $1.2 \mathrm{ml}$ phenol, $1.2 \mathrm{ml}$ chloroform/isoamyl alcohol (24:1); shaked for 5-10 min, and centrifuged at $3000 \mathrm{rpm}$ for $5 \mathrm{~min}$ at $10^{\circ} \mathrm{C}$. $25 \mu \mathrm{l}$ of $3 \mathrm{M}$ sodium acetate $(\mathrm{pH} 5.2)$ and $5 \mathrm{ml}$ ethanol was added with supernatant, shake until DNA was precipitated. DNA was washed with $70 \%$ ethanol, dried, dissolved in TE buffer and its concentration checked at 260 and $280 \mathrm{~nm} .5 \mu \mathrm{g}$ of total DNA and $0.5 \mu \mathrm{g}$ DNA standard per well were loaded on $1.5 \%$ agarose gel containing ethidium bromide. Electrophoresis was performed for 45 min with $100 \mathrm{~V}$ batteries, and DNA was observed under digital gel doc system and photographed.

\section{Histopathological study of tissue}

After weighting the portion specifies for histology small pieces of each tissue was fixed for 3-4 h in fixative sera followed by dehydration with ascending grades of alcohol (80\%, 90\%, and 100\%) and transferred in cedar wood oil. When tissue becomes clear then all tissues were embedded in paraplast and prepared blocks for further microtomy. 3-4 $\mu \mathrm{m}$ thin slides were prepared with microtome; wax was removed, stained with hemotoxilin-eosin and photographed under light microscope at $10 \times$ and $40 \times$.

\section{Statistical analysis}

To find the different treatment effects, one way analysis of variance was carried by computer software SPSS 13.0. Level of significance among the various treatments was determined by LSD at $0.05 \%$ level of probability.

\section{Results}

\section{Effects of $C$. opaca fruit against $\mathrm{CCl}_{4}$ induced pulmonary} toxicity in rat

$\mathrm{CCl}_{4}$ is a powerful pulmonary toxin that induces acute and chronic lung toxicity. This study induced pulmonary toxicity by $\mathrm{CCl}_{4}$ and determined the therapeutic effect of C. opaca fruit in $\mathrm{CCl}_{4}$ administered rats. Parameters studied included antioxidant enzymatic levels, genotoxicity and characteristic histological findings of lungs.

\section{Effects of $C$. opaca fruit on enzymatic antioxidant levels}

Oxidative stress can affect almost every organ including the lungs. ROS production is caused by oxidative stress that directly damages lipids, proteins and DNA. In reaction to this, the body has its own defense system that consists of antioxidant enzymes that limit the level of damage. The protective effects of different fractions of $C$. opaca fruit against $\mathrm{CCl}_{4}$-induced pulmonary changes of tissue proteins and antioxidant levels is shown in Table $1 . \mathrm{CCl}_{4}$ treatment considerably $(p<0.05)$ decreased tissue protein, catalase, peroxidase, and superoxide dismutase levels compared with the control group. Co-administration of EFC, HFC and MFC significantly $(p<0.05)$ increased antioxidant enzyme activity.

\section{Effects of $C$. opaca fruit on TBARS and $\mathrm{H}_{2} \mathrm{O}_{2}$}

The effects of $C$. opaca fruit on TBARS and $\mathrm{H}_{2} \mathrm{O}_{2}$ levels are shown in Table 2. Increased TBARS and $\mathrm{H}_{2} \mathrm{O}_{2}$ levels were due to $\mathrm{CCl}_{4}$ toxicity. Post-administration of various 
Table 1 Effects of various fractions of $C$. opaca fruit on tissue proteins and antioxidant enzyme levels

\begin{tabular}{lllll}
\hline Group & Protein $(\boldsymbol{\mu g} / \mathbf{m g}$ tissue $)$ & CAT $(\mathbf{U} / \mathbf{m i n})$ & POD $(\mathbf{U} / \mathbf{m i n})$ & SOD $(\mathbf{U} / \mathbf{m g}$ protein) \\
\hline Control & $2.01 \pm 0.03 f$ & $4.11 \pm 0.21 \mathrm{~d}$ & $10.42 \pm 0.53 \mathrm{~d}$ & $3.40 \pm 0.23 \mathrm{e}$ \\
Oil + DMSO & $1.96 \pm 0.03 f$ & $4.09 \pm 0.30 \mathrm{~d}$ & $11.00 \pm 0.20 \mathrm{~d}$ & $3.25 \pm 0.21 \mathrm{e}$ \\
$\mathrm{CCl}_{4}$ & $0.74 \pm 0.01 \mathrm{a}$ & $2.09 \pm 0.24 \mathrm{a}$ & $5.74 \pm 0.42 \mathrm{a}$ & $1.12 \pm 0.02 \mathrm{a}$ \\
$\mathrm{Sily}+\mathrm{CCl}_{4}$ & $1.49 \pm 0.02 \mathrm{e}$ & $3.60 \pm 0.11 \mathrm{c}$ & $9.64 \pm 0.23 \mathrm{c}$ & $2.59 \pm 0.10 \mathrm{~d}$ \\
$\mathrm{HFC}+\mathrm{CCl}_{4}$ & $0.89 \pm 0.03 \mathrm{~b}$ & $2.60 \pm 0.16 \mathrm{~b}$ & $6.53 \pm 0.32 \mathrm{~b}$ & $1.46 \pm 0.10 \mathrm{~b}$ \\
$\mathrm{EFC}+\mathrm{CCl}_{4}$ & $1.05 \pm 0.06 \mathrm{c}$ & $3.02 \pm 0.07 \mathrm{c}$ & $6.89 \pm 0.17 \mathrm{~b}$ & $1.51 \pm 0.08 \mathrm{~b}$ \\
$\mathrm{MFC}+\mathrm{CCl}_{4}$ & $1.35 \pm 0.078 \mathrm{~d}$ & $3.30 \pm 0.10 \mathrm{c}$ & $7.80 \pm 0.17 \mathrm{~b}$ & $2.20 \pm 0.13 \mathrm{c}$ \\
\hline
\end{tabular}

Values are Mean \pm SD (06 number). Sily = Silymarin.

a-f (Means with different letters) indicate significance at $p<0.05$.

fractions of C. opaca fruits appreciably $(p<0.05)$ ameliorated the toxic effects of $\mathrm{CCl}_{4}$ in lung tissues in contrast to the control group. Similar ameliorating effects were observed with silymarin administration, which had levels similar to the control group.

\section{Effects of $C$. opaca fruit on glutathione enzymes}

Phase II antioxidant metabolizing enzymes play a key role in the detoxification of oxidative stress. $\mathrm{CCl}_{4}$ insults significantly $(p<0.05)$ reduced the activities of glutathione enzymes such as glutathione S-transferase (GST), glutathione peroxidase (GPx) and glutathione reductase (GR) when compared with the control group (Table 3). Various fractions of $C$. opaca fruits significantly $(p<0.05)$ ameliorated toxicity by increasing the activity of phase II antioxidant enzymes towards control group levels. Silymarin administration to rats significantly $(p<0.05)$ reduced toxicity and restored the activities of GST, GPx and GR in lung tissues.

Effects of C. opaca fruit on GSH, QR and DNA fragmentation Glutathiones and DNA play important roles in free radicalinduced detoxification. Administration of $\mathrm{CCl}_{4}$ significantly reduced $(p<0.05)$ both GSH and QR content, and significantly $(p<0.05)$ increased DNA fragmentation (Table 4$)$.

Table 2 Effects of various fractions of $C$. opaca fruit on tissue TBARS and $\mathrm{H}_{2} \mathrm{O}_{2}$

\begin{tabular}{lll}
\hline Group & $\begin{array}{l}\text { TBARS } \\
\text { (nM/min/mg protein) }\end{array}$ & $\begin{array}{l}\mathbf{H}_{2} \mathbf{O}_{2} \\
\text { (nM/min/mg tissue) }\end{array}$ \\
\hline Control & $3.13 \pm 0.18 \mathrm{c}$ & $1.21 \pm 0.074 \mathrm{f}$ \\
Oil + DMSO & $3.20 \pm 0.13 \mathrm{c}$ & $1.17 \pm 0.051 \mathrm{f}$ \\
$\mathrm{CCl}_{4}$ & $5.41 \pm 0.68 \mathrm{a}$ & $2.64 \pm 0.062 \mathrm{a}$ \\
$\mathrm{Sily}+\mathrm{CCl}_{4}$ & $4.02 \pm 0.47 \mathrm{~b}$ & $1.53 \pm 0.058 \mathrm{e}$ \\
$\mathrm{HFC}+\mathrm{CCl}_{4}$ & $4.91 \pm 0.11 \mathrm{a}$ & $2.24 \pm 0.035 \mathrm{~b}$ \\
$\mathrm{EFC}+\mathrm{CCl}_{4}$ & $4.89 \pm 0.15 \mathrm{a}$ & $2.21 \pm 0.043 \mathrm{~b}$ \\
$\mathrm{MFC}+\mathrm{CCl}_{4}$ & $4.07 \pm 0.23 \mathrm{~b}$ & $1.99 \pm 0.094 \mathrm{c}$ \\
\hline
\end{tabular}

Values are Mean \pm SD (06 number). Sily= Silymarin.

$a-f($ Means with different letters) indicate significance at $p<0.05$.
Treatment of rats with various fractions of $C$. opaca significantly $(p<0.05)$ restored DNA fragmentation and GSH and QR activity compared with the $\mathrm{CCl}_{4}$ group. Silymarin also showed significant protection against $\mathrm{CCl}_{4}$.

Effects of $C$. opaca fruit on DNA damages (ladder assay) $\mathrm{CCl}_{4}$ is a genotoxic chemical and causes DNA damages. The protective effects of various fractions of $C$. opaca fruit against $\mathrm{CCl}_{4}$ induced DNA damages in rats are shown by DNA ladder assay in Figure 1. Intact genomic DNA was revealed by ladder assay of control group while, $\mathrm{CCl}_{4}$ group showed marked DNA damages. Co-treatment of silymarin and various fractions viz; HFC, EFC and MFC proved the recovering effects by DNA band pattern showing similarity with control group.

\section{Effects of $C$. opaca fruit on lung histoarchitecture}

The effects of various fractions of $C$. opaca fruits against $\mathrm{CCl}_{4}$ induced lung injury and histological changes were observed. Histological assessments of lung tissues of control and DMSO group confirmed the typical cellular architecture with distinct alveolar septa and bronchioles, structured Clara cells and fibroblasts as shown in Figure 2A and B, respectively. Aggregation of fibroblasts, collagen fibres, ruptured alveolar bronchioles and walls, disorganized Clara cells showing pulmonary edema and interstitial hemorrhage were found in $\mathrm{CCl}_{4}$ intoxicated rats (Figure 2C). The lung sections of rats treated with various fractions of C. opaca fruits viz; EFC and MFC intoxicated with $\mathrm{CCl}_{4}$ (Figure 2E-F), showed normal structure of alveolar bronchioles and less degenerative changes with various degrees in case of each group, supplementing the protective effects of the plant samples. Post-administrations of silymarin reduced the toxic effects of $\mathrm{CCl}_{4}$ and reversed the histopathology towards the control group (Figure 2D). Present histological observations are in agreement with the results of pulmonary oxidative stress level.

\section{Discussion}

Lungs are the site of respiration and are exposed to the action of toxic chemicals, drugs or smoking. Toxin inhalation 
Table 3 Effects of various fractions of C. opaca fruit on GST, GPx and GSH

\begin{tabular}{llll}
\hline Group & GST (nM/min/mg protein) & GPx (nM/min/mgprotein) & GR (nM/min/mg protein) \\
\hline Control & $170.29 \pm 4.28 \mathrm{~h}$ & $114.21 \pm 3.29 \mathrm{~g}$ & $247.01 \pm 6.00 \mathrm{~g}$ \\
Oil + DMSO & $177.43 \pm 4.31 \mathrm{~h}$ & $108.48 \pm 3.12 \mathrm{~g}$ & $236.23 \pm 5.73 \mathrm{~g}$ \\
$\mathrm{CCl}_{4}$ & $92.13 \pm 3.48 \mathrm{a}$ & $65.08 \pm 3.32 \mathrm{a}$ & $136.24 \pm 3.72 \mathrm{a}$ \\
$\mathrm{Sily}+\mathrm{CCl}_{4}$ & $161.34 \pm 3.22 \mathrm{~g}$ & $101.48 \pm 2.81 \mathrm{f}$ & $192.41 \pm 4.07 \mathrm{e}$ \\
$\mathrm{HFC}+\mathrm{CCl}_{4}$ & $99.61 \pm 2.03 \mathrm{~b}$ & $73.40 \pm 1.45 \mathrm{~b}$ & $149.32 \pm 4.56 \mathrm{~b}$ \\
$\mathrm{EFC}+\mathrm{CCl}_{4}$ & $105.34 \pm 2.51 \mathrm{c}$ & $72.02 \pm 1.81 \mathrm{~b}$ & $154.66 \pm 4.39 \mathrm{~b}$ \\
$\mathrm{MFC}+\mathrm{CCl}_{4}$ & $130.80 \pm 3.73 \mathrm{e}$ & $83.52 \pm 2.40 \mathrm{~d}$ & $177.46 \pm 4.29 \mathrm{~d}$ \\
\hline
\end{tabular}

Values are Mean \pm SD (06 number). Sily = Silymarin.

a-f (Means with different letters) indicate significance at $p<0.05$.

is often injurious to health and can cause pulmonary disease. Lungs are often injured by oxidative stress. A biochemical study suggested $\mathrm{CCl}_{4}$ free radicals could have the same consequences [2]. Pulmonary toxicity causes notable pathological effects such as fibrosis, inflammatory changes and degeneration of epithelial cells. Symptoms of pulmonary toxicity include fibrosis, inflammatory response, and degeneration of epithelial cells. Therefore, this study investigated the pharmacological outcomes of different plant extracts and their fractions on $\mathrm{CCl}_{4}$-induced oxidative damage in rat lungs [22]. The potency of natural antioxidants depends on their chain breaking capacity, declining hydrogen peroxide levels, scavenging superoxides and chelating transitory metal ions [23]. Food scientists and nutrition specialists suggest that plants are useful as a source of natural antioxidants that contribute to reducing risks of certain diseases, such as cancer and cardiovascular disease. In this context, intake of plants might prevent the onset of these diseases [24]. Food deterioration is brought about by lipid peroxidation. The use of synthetic drugs as preservative agents to inhibit lipid peroxidation are strictly prohibited as they are potent carcinogens [25]. Consequently, these chemical therapeutics/synthetic drugs should be replaced with naturally occurring agents having no or very few side-effects. A previous study verified that a diet high in vegetables and fruits is associated with a decline in

Table 4 Effects of various fractions of $C$. opaca fruit on GSH, QR and DNA fragmentation

\begin{tabular}{llll}
\hline Group & $\begin{array}{l}\text { GSH } \\
(\boldsymbol{\mu M} / \mathbf{g} \text { tissue })\end{array}$ & $\begin{array}{l}\text { QR } \\
(\mathbf{n M} / \mathbf{m i n} / \mathbf{m g} \text { protein })\end{array}$ & DNA damages \% \\
\hline Control & $27.07 \pm 1.41 \mathrm{e}$ & $119.18 \pm 3.03 \mathrm{~g}$ & $12.82 \pm 1.38 \mathrm{e}$ \\
Oil + DMSO & $24.23 \pm 1.50 \mathrm{e}$ & $124.27 \pm 3.68 \mathrm{~g}$ & $13.53 \pm 1.98 \mathrm{e}$ \\
$\mathrm{CCl}_{4}$ & $10.23 \pm 0.65 \mathrm{a}$ & $60.74 \pm 2.13 \mathrm{a}$ & $61.42 \pm 2.70 \mathrm{a}$ \\
$\mathrm{Sily}+\mathrm{CCl}_{4}$ & $20.53 \pm 1.41 \mathrm{~d}$ & $104.47 \pm 3.22 \mathrm{f}$ & $19.19 \pm 1.48 \mathrm{~d}$ \\
$\mathrm{HFC}+\mathrm{CCl}_{4}$ & $11.65 \pm 0.46 \mathrm{~b}$ & $66.18 \pm 2.87 \mathrm{~b}$ & $33.26 \pm 0.72 \mathrm{~b}$ \\
$\mathrm{EFC}+\mathrm{CCl}_{4}$ & $11.90 \pm 0.57 \mathrm{~b}$ & $73.30 \pm 3.17 \mathrm{c}$ & $33.47 \pm 0.48 \mathrm{~b}$ \\
$\mathrm{MFC}+\mathrm{CCl}_{4}$ & $15.79 \pm 1.00 \mathrm{c}$ & $91.26 \pm 2.32 \mathrm{e}$ & $20.33 \pm 1.54 \mathrm{~d}$ \\
\hline
\end{tabular}

Values are Mean \pm SD (06 number). Sily = Silymarin.

$a-h$ (Means with different letters) indicate significance at $p<0.05$. degenerative diseases [26], thus natural antioxidants, flavonoids and phenolic compounds have gained considerable attention. Structurally, phenolic compounds contain a conjugated ring with a hydroxyl group, and can act as an antioxidant by preventing free radical-mediated diseases. Plant antioxidant capacity is characterized by quenching free radicals such as lipid peroxy radicals, singlet oxygen and superoxide anions [27]. Combinatorial methods are required to explore the antioxidant tendency of natural resources because no single assay can reflect all antioxidants in a mixed assay or the complex nature of phytochemicals. Adedapo et al. [28] reported the scavenging abilities of plant extracts against free radicals in a complex assay system to eradicate the radical-related pathological diseases. Toxic compounds of drugs and xenobiotics are metabolized by the glutathione system (reduced glutathione, glutathione reductase, glutathione peroxidase and glutathione-S-transferase). Administration of $C$. opaca reduced $\mathrm{CCl}_{4}$ toxicity, thereby increasing the activity of GST, GSR, GSH-Px and QR [29,30]. Similar observations were reported by Khan et al. [31], when administering melatonin against $\mathrm{CCl}_{4}$-induced oxidative stress. Free radicals cause lipid peroxidation, elevate TBARS and deplete tissue GSH contents [32]. In the present study, low levels of GSH were accompanied by elevated levels of TBARS and $\mathrm{H}_{2} \mathrm{O}_{2}$ compared with the control group. Fruit extracts of $\mathrm{C}$. opaca were characterized by the high expression level of GSH contents with low level of TBARS and $\mathrm{H}_{2} \mathrm{O}_{2}$. Similar observations were reported during co-treatment of plant extracts against $\mathrm{CCl}_{4}$-induced damage in rats [33]. Lipid peroxidation induced by $\mathrm{CCl}_{4}$ disturbs protein synthesis but can also diffuse into the nucleus, causing DNA fragmentation $[34,35]$ that can lead to pulmonary damages. In the present study, $\mathrm{CCl}_{4}$-induced DNA damage was significantly ameliorated by $C$. opaca as reported previously by Khan et al. [36]. Extensive variations were observed during histopathological study of rat lungs. $\mathrm{CCl}_{4}$ damage of the alveolar septa and mobbing of blood capillaries resulted in the accumulation of blood cells and collagen fibers at various places causing an endemic condition. Similar observations were found in rat lungs in previous studies during $\mathrm{CCl}_{4}$ 


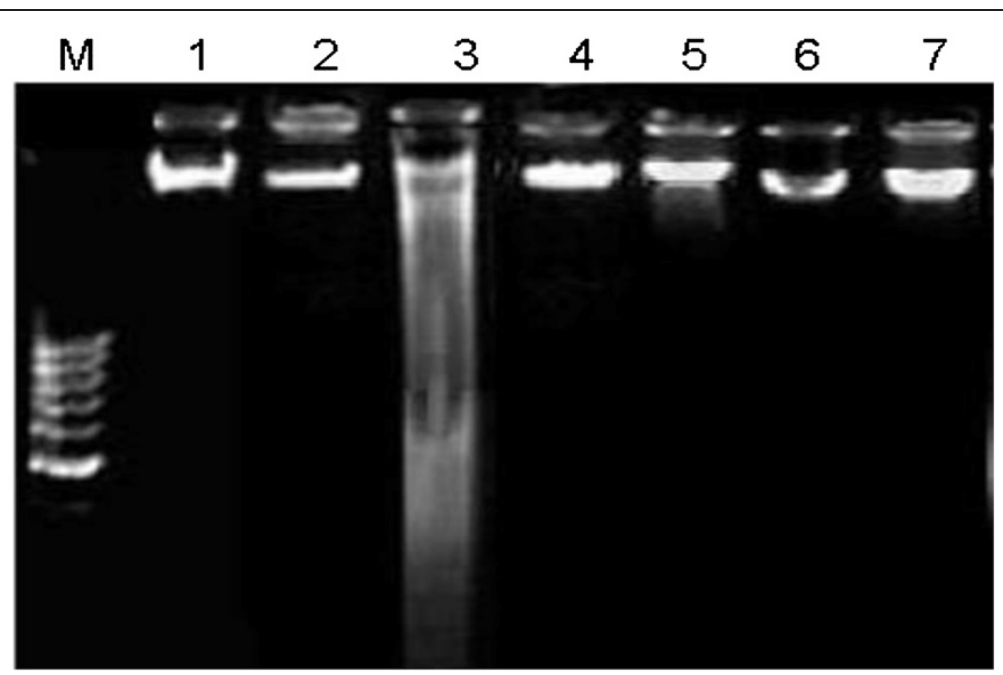

Figure 1 Agarose gel showing DNA damage by $\mathrm{CCl}_{4}$ and protective effects of various fractions of $C$. opaca fruit in pulmonary tissue. Lanes from left (M) low molecular weight marker, (1) control, (2) DMSO + Olive oil group, (3) $\mathrm{CCl}_{4}$ group, (4) Silymarin $+\mathrm{CCl}_{4} \mathrm{group}$, (5) $\mathrm{MFC}+\mathrm{CCl}_{4}$ group, (6) $\mathrm{EFC}+\mathrm{CCl}_{4}$ group, (7) $\mathrm{HFC}+\mathrm{CCl}_{4}$ group.

A

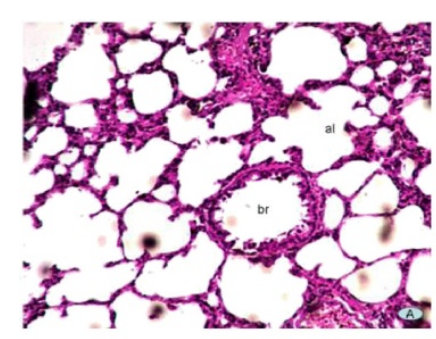

C

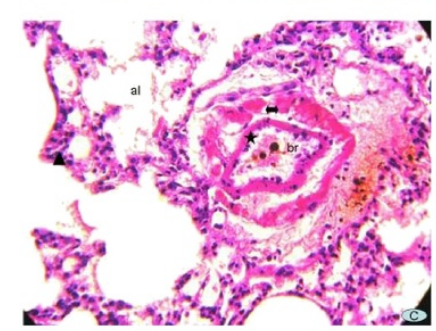

$\mathrm{E}$

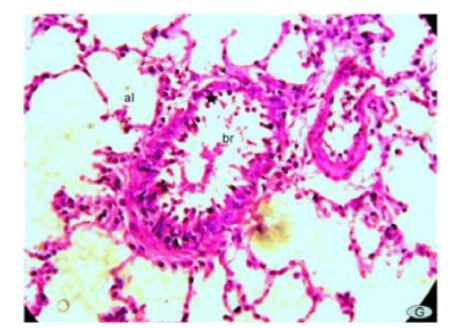

B

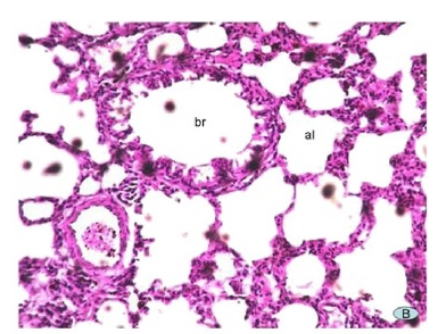

$\mathrm{D}$

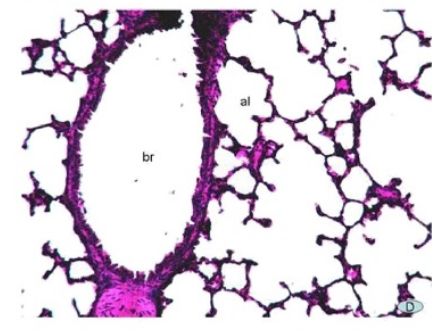

$\mathrm{F}$

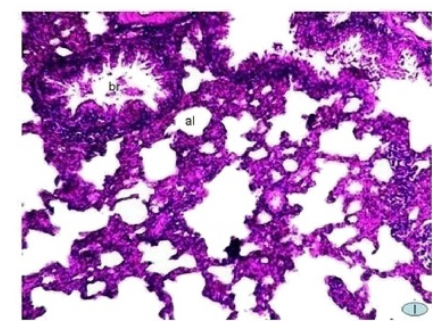

Figure 2 Microphotograph of rat lungs (H \& E stain) (A) Representative section of lungs from the control group showing normal histology, (B) DMSO + Olive oil group, (C) $\mathrm{CCl}_{4}$ group, (D) Silymarin $+\mathrm{CCl}_{4}$ group, (E) (E) $\mathrm{MFC}+\mathrm{CCl}_{4}$ group, (F) $\mathrm{EFC}+\mathrm{CCl} \mathrm{group}_{4}$ (al) alveolar space, (br) bronchioles, $(\boldsymbol{\star})$ collapsed inner epithelial layer, $(\boldsymbol{A})$ ruptured muscular layer with disorganized Clara cells, $(\mathbf{\Lambda})$ aggregation of fibroblasts. 
administration [37]. Co-treatment with $C$. opaca repaired pulmonary damage, as demonstrated by normal spaces in the alveoli, reduced cellular degeneration of alveoli and bronchioles as well as normalized pneumocytes as previously reported by Khan et al. [38] during Sonchus asper administration against $\mathrm{CCl}_{4}$-induced injuries in rats.

\section{Conclusion}

The present results revealed that C. opaca comprised of bioactive compounds; presenting protective effects against $\mathrm{CCl}_{4}$ induced toxic effects in lungs of rat. Further studies of isolation and purification of these constituents are in progress in our lab.

\section{Competing interests}

The authors declare that they have no competing interests.

\section{Authors' contributions}

SS made significant contribution to acquisition of data, analysis, conception, design of the manuscript. MRK and RAK (ORCID ID: 0000-0003-0453-2090) made significant contribution to acquisition of data, analysis, drafting and conception. All the authors read and approved the final manuscript.

\section{Acknowledgements}

We are very thankful to Higher Education Commission (HEC) Pakistan for provision research funds.

\section{Author details}

${ }^{1}$ Botanical Sciences Division, Pakistan Museum of Natural History, Garden Avenue, Shakarparian, Islamabad, Pakistan. 'Department of Biotechnology, University of Science and Technology, Bannu, KPK, Pakistan. ${ }^{3}$ Department of Biotechnology, Faculty of Biological Sciences, University of Science and Technology, Bannu, KPK 28100, Pakistan.

Received: 15 February 2013 Accepted: 28 January 2014

Published: 30 January 2014

\section{References}

1. Weber LW, Boll M, Stampfl A: Hepatotoxicity and mechanism of action of haloalkanes: carbon tetrachloride as a toxicological model. Crit Rev Toxicol 2003, 33:105-136.

2. Flaherty KR, Toews GB, Travis WD, Colby TV, Kazerooni EA, Gross BH, Jain A, Strawderman RL III, Paine R, Flint A: Clinical significance of histological classification of idiopathic interstitial pneumonia. Eur Respir J 2002, 19:275-283.

3. Kinnula VL, Crapo JD, Raivio KO: Generation and disposal of reactive oxygen metabolites in the lung. Lab Invest 1995, 73:3-19.

4. Kinnula VL, Crapo JD: Superoxide dismutases in the lung and human lung diseases. Am J Respir Crit Care Med 2003, 167:1600-1619.

5. Umamaheswari $M$, Chatterjee TK: In vitro antioxidant activities of the fractions of Coccinnia grandis L. leaf extract. Afric J Trad Compl Alter Med 2008, 5(1):61-73.

6. Kil HY, Seong ES, Ghimire BK, Chung I-M, Kwon SS, Goh EJ, Hoe K, Kim MJ, Lim JD, Lee D, Yu CY: Antioxidant and antimicrobial activities of crude sorghum extract. Food Chem 2009, 115:1234-1239.

7. Nazimuddin S, Qaiser M: Apocynaceae. In Flora of Pakistan. Edited by Nasir E, Ali SI. Karachi: Department of Botany, University of Karachi; 1983:11-13.

8. Jabeen A, Khan MA, Ahmad M, Zafar M, Ahmad F: Indigenous uses of economically important flora of Margalla Hills National Park, Islamabad Pakistan. Afric J Biotechnol 2009, 8(5):763-784.

9. Abbasi AM, Khan MA, Ahmad M, Zafar M, Khan H, Muhammad M, Sultana S: Medicinal plants for the treatment of jaundice and hepatitis based on socio-economic documentation. Afric J Biotechnol 2009, 8(8):1643-1650.

10. Adhikari BS, Babu MM, Saklani PL, Rawat GS: Distribution, use pattern and prospects for conservation of medicinal shrubs in Uttaranchal State. India. J Mountain Sci 2007, 4(2):155-180.
11. Ahmad SS, Mahmood F, Dogar Z-UL-H, Khan ZI, Ahmad K, Sher M, Mustafa I, Valeem EE: Priortization of medicinal plants of Margala Hills National Park, Islamabad on the basis of available information. Pakistan J Bot 2000, 41(5):2105-2114.

12. Chance B, Maehly AC: Assay of catalase and peroxidases. Methods in Enzymology 1955, 11:764-775.

13. Kakkar P, Das B, Viswanathan PN: A modified spectrophotomateric assay of superoxide dismutase. Indian J Biochem Biophys 1984, 21:130-132.

14. Habig WH, Pabst MJ, Jakoby WB: Glutathione-S-transferases: the first enzymatic step in mercapturic acid formation. J Biol Chem 1974, 249:7130-7139.

15. Carlberg I, Mannervik EB: Glutathione level in rat brain. J Biol Chem 1975, 250:4475-4480.

16. Mohandas J, Marshal JJ, Duggin GG, Horvath JS, Tiller DJ: Differential distribution of glutathione and glutathione-related enzymes in rabbit kidney. Possible implications in analgesic nephropathy. Biochem Pharmacol 1984, 33:1801-1807.

17. Benson AM, Hunkeler MJ, Talalay P: Increase of NADPH, quinone reductase activity by dietary antioxidant: Possible role in protection against carcinogenesis and toxicity. Proc Nati Acad Sci USA 1990, 77:5216-5220.

18. Jollow DJ, Mitchell JR, Zampaglione N, Gillete JR: Bromobenzene induced liver necrosis. Protective role of glutathione and evidence for 3 , 4-bromobenzene oxide as a hepatotoxic metabolite. Pharmacol 1974, 1:151-169.

19. Iqbal M, Sharma SD, Zadeh HR, Hasan N, Abdulla M, Athar M: Glutathione metabolizing enzymes and oxidative stress in ferric nitrilotriacetate (Fe-NTA) mediated hepatic injury. Redox Report 1996, 2:385-391.

20. Pick A, Keisari Y: Superoxide anion and hydrogen peroxide production by chemically elicited peritoneal macrophages-induction by multiple nonphagocytic stimuli. Cell Immunol 1981, 59:301-318.

21. Wu JH, Tung YT, Chien SC, Wang SY, Kuo YH, Shyur LF, Chang ST: Effect of phytocompounds from the Heart-wood of Acacia confusa on inflammatory mediator production. J Agric Food Chem 2008, 56:1567-1573.

22. Khan RA, Khan MR, Sahreen S: Protective effect of Launaea procumbens (L.) on lungs against $\mathrm{CCl}_{4}$. BMC Compl Altere Med 2012, 12:133.

23. Dorman HJD, Peltoketo A, Hiltunen R, Tikkanen MJ: Characterization of the antioxidant properties of de-odourised aqueous extracts from selected Lamiaceae herbs. Food Chem 2003, 83:255-262.

24. Ruch RJ, Cheng SJ, Klaunig JE: Prevention of cytotoxicity and inhibition of intercellular communication by antioxidant catechins isolated from Chinese green tea. Carcinogenesis 1989, 10:1003-1008.

25. Whysner J, Wang CX, Zang E, latropoulos MJ, Williams GM: Dose response of promotion of butylated hydroxyanisole in chemically initiated tumors of the rat forestomach. Food Chem Toxicol 1994, 32:215-222.

26. Babu BH, Shylesh BS, Padikkala J: Antioxidant and hepatoprotective effect of Alanthus icicifocus. Fitoterapia 2001, 72:272-277.

27. Robak J, Dryglewski RJ: Flavonoids are scavengers of superoxide anion. Biochem Pharmacol 1988, 37:83-88.

28. Adedapo AA, Jimoh FO, Koduru S, Masika PJ, Afolayan AJ: Evaluation of medicinal potentials of the methanol extracts of the leaves and stems of Halleria lucida. Bioresource Tech 2008, 99:4158-4163.

29. Manna P, Sinha M, Sil PC: Aqueous extract of Terminalia arjuna prevents carbon tetrachloride induced hepatic and renal disorders. BMC Compl Alter Med 2006, 6:33.

30. Hassan SA, Rizk MZ, El-Sharkawi F, Badary O, Kadry MO: The possible synergistic role of phytic acid and catechin in ameliorating the deteriorative biochemical effects induced by carbon tetrachloride in rats. J App/ Sci Res 2007, 3:1449-1459.

31. Khan RA, Khan MR, Sahreen S, Bukhari J: Prevention of $\mathrm{CCl}_{4}$-induced nephrotoxicity with Sonchus asper in rat. Food Chem Toxicol 2010, 23:1304-1321.

32. Khan RA, Khan MR, Sahreen S: Estimation of flavoniods, antimicrobial, antitumor and anticancer activity of Carissa opaca fruits. BMC Compl Alter Med 2013, 13:372

33. Sreelatha S, Padma PR, Umadevi M: Protective effects of Coriandrum sativum extracts on $\mathrm{CCl} 4$-induced hepatotoxicity in rats. Food Chem Toxicol 2008, 48:702-708.

34. Marnett $\mathrm{U}$ : Oxyradicals and DNA damage. Carcinogenesis 2000, 21:361-70.

35. Sahreen S, Khan MR, Khan RA: Hepatoprotective effects of methanol extract of Carissa opaca leaves on CCl4-induced damage in rat. BMC Compl Alter Med 2011, 11:48. 
36. Khan MR, Rizvi W, Khan GN, Khan RA, Shaheen S: Carbon tetrachloride induced nephrotoxicity in rat: Protective role of Digera muricata (L.) Mart. J Ethnopharmacol 2009, 122:91-99.

37. Zakaria I, Khalik IAE, Selim ME: The protective effects of curcumin against carbon tetrachloride induced pulmonary injury in rats. Egypt J Med Lab Sci 2004, 13:1-15.

38. Khan RA, Khan MR, Sahreen S: Protective effect of Sonchus asper extracts against experimentally-induced lung injuries in rats: A novel study. Exp Toxicol Pathol. doi:10.1016/j.etp.2011.01.007.

doi:10.1186/1472-6882-14-40

Cite this article as: Sahreen et al.: Effects of Carissa opaca fruits extracts on oxidative pulmonary damages and fibrosis in rats. $B M C$

Complementary and Alternative Medicine 2014 14:40.

\section{Submit your next manuscript to BioMed Central and take full advantage of:}

- Convenient online submission

- Thorough peer review

- No space constraints or color figure charges

- Immediate publication on acceptance

- Inclusion in PubMed, CAS, Scopus and Google Scholar

- Research which is freely available for redistribution 